\title{
Stranger Danger: Social Distancing, the Bubble, and the War on Space in Times of Covid-19
}

\section{Sarah Marusek $^{1}$ (D) $\cdot$ Anne Wagner ${ }^{2}$ (D) Aleksandra Matulewska ${ }^{3} \mathbb{C}$}

Accepted: 25 June 2021 / Published online: 13 November 2021

(c) The Author(s), under exclusive licence to Springer Nature B.V. 2021

\begin{abstract}
As authors, we recognize the scientific foundations for implementing social distancing in preventing the spread of Covid-19. Yet, we also recognize fundamental changes to the socio-legal discourse of everyday life that we research. We see legalized space itself as the foundation for social relationships significantly impacted through the 'new normal' of social/physical distancing guidelines. This paper will explore the positionalities of bodies that contribute to the transformation of cultural spaces and social interactions against the legalized backdrop of combatting viral spread of Covid-19 in the United States, France, and Poland.
\end{abstract}

Keywords Social distancing · Physical distancing $\cdot$ Spatiality $\cdot$ Legal culture Covid-19

There is an entire universe of behaviour that is unexplored, unexamined, and very much taken for granted. It functions outside conscious awareness and in juxtaposition to words [4, p.17]

Sarah Marusek

marusek@hawaii.edu

Anne Wagner

valwagnerfr@yahoo.com

Aleksandra Matulewska

aleksandra.matulewska@gmail.com

1 University of Hawai 'I Hilo, Hilo, HI, USA

2 ULR 4487 - CRDP - Centre de Recherche Droits Et Perspectives du Droit, University of Lille, 59000 Lille, France

3 Adam Mickiewicz University, Poznań, Poland 


\section{Introduction}

Since March 2020, public interactions have undergone significant transformation. Efforts have been made to physically separate bodies from one another in cultural spaces. Legally, laws of social distancing have been enacted whereby bodies do not congregate either in queues or in groups. Socially, these mandates have changed how life is practiced through everyday routines. Through attempts to limit the spread of Covid-19 during this global pandemic have meant that people cannot be so close together. At its most basic aspect, the separation of bodies decreases the likelihood that breath-based droplets of potential coronavirus will travel and infect. At schools, in restaurants, in line at the grocery store, at the movie theater, at bars, at parties, even in parks, social distancing mandates of six feet have become the spatial norm in the age of Covid-19. Wherever there are queues, gatherings, or public seating, the regulation of the positionality of bodies and the potential fear of 'stranger danger' results in the spatialized transformation of cultural activities and everyday banalities. This paper will examine this thesis as it happens in American, French, and Polish contexts to show the ways in which legal regulations meant to curb not only the spread of Covid-19 but also the nuances of public living in Western culture.

\section{Social Distancing Guidelines}

Despite increasing numbers of infection and death throughout the population in the global leader of pandemic infection, social distancing in the United States was politicized under former President Trump as a bothersome overreaction to Covid-19. In April 2020, 6 months ahead of the 2020 Presidential Election, Trump stated:

We're going to start to move around and hopefully in the not-too-distant future, we'll have some massive rallies and people will be sitting next to each other," he said, adding that having people spaced out in accordance with social distancing guidelines "wouldn't look too good. [1].

In contrast to former President Trump's visible need to hold super-spreader events where hundreds of unmasked supporters come in close contact with one another, Presidential Candidate Joe Biden asserted “This isn't about politics. It's about saving lives" [29]. Science tells us that such parameters between people decreases viral transmission as the sheer distance that breath droplets can travel is abbreviated. Government agencies, such as the United States Centers for Disease Control (CDC) have declared that six feet is the realm of safety needed to combat the spread of this coronavirus. In public transportation, social gatherings, shopping, dining out, even exercise, the social becomes the physical through the recognition of the role of spatiality in calls to socially, or physically distance:

Social distancing, also called "physical distancing," means keeping a safe space between yourself and other people who are not from your household. To practice social or physical distancing, stay at least 6 feet (about 2 arm lengths) 
from other people who are not from your household in both indoor and outdoor spaces. ${ }^{1}$

Since January 2021, President Biden and Vice President Kamala Harris have emphasized the scientific logic of social distancing for its essential role in stopping viral spread. In a resurrected effort to use science rather than politics as the basis for policies made in conjunction with Covid-19, the White House's official website states [29]:

Social distancing is not a light switch. It is a dial. President Biden will direct the CDC to provide specific evidence-based guidance for how to turn the dial up or down relative to the level of risk and degree of viral spread in a community, including when to open or close certain businesses, bars, restaurants, and other spaces; when to open or close schools, and what steps they need to take to make classrooms and facilities safe; appropriate restrictions on size of gatherings; when to issue stay-at-home restrictions.

Biden's metaphor of the dial is a statement of control over space through government mandate. Because the space of cultural life is a continual production of spontaneous, unregulated relationships and social events, turning the dial up or down according to relative risk subjects the movement of everyday life to a level of surveillance expressed in various ways through space-based limitation and restriction. In this war on Covid-19, we find ourselves in a war on the serendipity of social space.

The same applies in the Republic of France. Indeed, the French former Prime Minister Edouard Philippe delivered a speech where he first emphasized on "social distancing", individual physical limitations and space restrictions on 14 March 2020:

I'm not telling you it's a nice term. I know we French people don't like it, because we are a people who love gathering together, a joyful people, happy to live together, perhaps even a little more so when the fear begins to take hold [...]

I say it with gravity, we must, all together, show more discipline in the application of measures. What we need to do at the moment is simply to avoid gathering as much as possible, to limit friendly and family gatherings, to use public transport only to go to work and only if your physical presence at work is indispensable, to leave your home only to do essential shopping, to get some exercise or to vote [...]. [21] (our translation)

France always tends to follow the recommendations of the WHO to

Maintain at least a 1-metre distance between yourself and others to reduce your risk of infection when they cough, sneeze or speak. Maintain an even

\footnotetext{
${ }^{1}$ https://www.cdc.gov/coronavirus/2019-ncov/prevent-getting-sick/social-distancing.html. Accessed 2 March 2020.
} 
greater distance between yourself and others when indoors. The further away, the better. ${ }^{2}$

While recommendation can be regulated in public spaces, the same does not apply in private spaces. For last Christmas Eve, Emmanuel Macron, in his speech, called on people to

breathe a little and get together, yes, but I appeal to your sense of responsibility [...]. Private gatherings must limit the number of adults in the same room at the same time and we must all ensure that we respect the health rules between us to protect everyone [17] (our translation).

This is a recommendation for regulation in the private sphere that cannot be imposed, but suggested by common sense. Rémi Salomon, the President of the Medical Commission of AP-HP (public assistance-hospitals of Paris), went even further, creating de facto controversy by advising to isolate the elderly in the kitchen at Christmas:

we cut the Christmas cake in two and grandma and grandpa eat in the kitchen and we eat in the dining room [24].

Whereas the authorities now prefer the term "physical distance" rather than "social distancing" in public space, the recommended minimum spacing between each person has now been increased on January 2021 to $2 \mathrm{~m}$ when face masks are not worn [8, art. 1], given the increase in English and South African variants. That is the reason why for collective catering, the same table may only be occupied by people coming together or having booked together, with a limit now set at 4 people instead of 6 . A minimum distance of $2 \mathrm{~m}$ must be guaranteed between each seated person, unless a fixed or removable wall provides physical separation. [9, art. 40]. But this limitation seems to differ for school canteens, for which it would apparently not apply. [16]

Furthermore, social distancing represents the latest advances in scientific research on Covid-19 transmission patterns, all of which seek to resolve the multiple unknowns in Covid-19 equation. The margins between the recommendations of 1-2 $\mathrm{m}$ indicate the many pieces of data that are still missing to understand the mechanisms at work in the virus spread. This is well documented in a video posted online, not to mention the rather unpredictable "wind" factor that must also be taken into account (Fig. 1).

The situation in Poland is to some extent different from the very beginning. Given the number of inhabitants, the numbers of infected and admitted people to hospitals from the very beginning is limited in comparison with France, Italy, Spain or neighboring Germany. The Polish Minister of Health, Łukasz Szumowski, was informed about the first person diagnosed as infected with SARS-CoV-2 in the territory of Poland on 4 March 2020 [28]. The following days brought reports of other infected

${ }^{2}$ https://www.who.int/emergencies/diseases/novel-coronavirus-2019/advice-for-public Accessed 2 March 2020. 


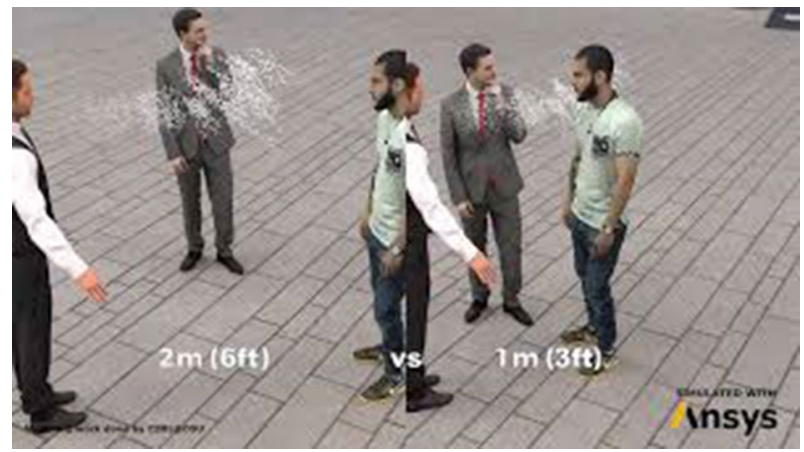

Fig. 1 Social distancing guidelines. Source: Simulation de la propagation des gouttelettes [26]

patients. With the number of infected growing slowly day by day, the Polish government started introducing restrictions in an attempt to avoid a rapid spread of pandemic. As the Prime Minister Mateusz Morawiecki announced:

We want to avoid what happened to the countries of Western Europe at all costs, [and] We cannot afford to relax. We must do everything to avoid the worst-case scenario [...] We must strictly follow the rules of social distancing.

This is one and the basic rule that will allow us to fight this disease. [6]

What actually happened in the wake of new, so far unknown restrictions of social distancing, was a number of opposing reactions in Poland. On the one hand, Facebook posts of the Prime Minister Office were flooded with comments on the absurdity of social distancing, especially among family members and the task's unfeasibility. On the other hand, appeals to reason and to respect the new restrictive law were also published. Social distancing in public spaces turned out to be an extremely controversial issue on March and April 2020. After a long period of bad weather and lack of sun in Poland during autumn and winter months, which actually make Poles close themselves in the warmth of their homes, spring shifts people's habits. Inhabitants crave for walks in the open air and wait for pavement cafes and pubs to start operating. Spring 2020 turned out to be a complete shock for Polish citizens. The restrictions were introduced by regulations published at regular intervals of a few weeks, with one of the first impositions being published on 31 March $2020 .^{3}$ Not only were citizens recommended to stay at home and refrain from meeting their family members and friends at the moment when the weather started improving and Easter family festivities approached, but also walks for pleasure were forbidden. A new ban entered into force on 1 April 2020, stipulating that every person under 18 could leave the house only under the supervision of an adult guardian. At the same time, parks being the green lungs of cities, boulevards and beaches were closed to the public too. The government introduced significant penalties for breaching the

\footnotetext{
${ }^{3}$ https://isap.sejm.gov.pl/isap.nsf/download.xsp/WDU20200000566/O/D20200566.pdf Accessed 25 March 2020.
} 
bans, from PLN5000 to PLN30,000. The National Forests forbade entering state forests and national parks on 3 April 2020. The public immediately reacted. Lawyers and the Polish Commissioner for Human Rights published an open letter to the Minister of Environment, pillorying the decision of the National Forests indicating that the ban was illegal. [19] The hell broke out in a way as citizens started to harangue the ban indicating its discriminatory features. The question emerged whether hunters were allowed to enter forests during pandemic to combat African Swine Fever animal pandemic, whereas other citizens were not allowed to take care of their mental and physical health. The social outrage was incredibly strong and instantaneously the public announcements followed informing than no one could enter forests, including hunters. The government withdrew this ban under the Regulation of the Council of Ministers of 19 April 2020, and set up certain restrictions, orders and bans in connection with the epidemic. ${ }^{4}$ Kids were still not allowed to play in playgrounds of various sorts or visit zoological gardens, but walks were no longer forbidden. This war for the right to spend time outside in public space such as Facebook, Twitter, and other social media was excruciating and ruthless. The government of the Republic of Poland, after the wave of heavy criticism, did not enforce other limitations of freedom and allowed citizens to go outside for recreational purposes. However, the obligation to keep the distance of $2 \mathrm{~m}$ must be kept if persons walking together do not live in a common household. Social distancing in stores, bars, restaurants, buses, etc. has been criticized to some extent, but the ban has been followed in general. However, this public war revealed the ongoing pressure for equality in and before law. Every instance of public appearance of celebrities, politicians, members of Parliament, etc. without a mask or face cover or without proper social distancing has been quickly spotted by citizens, and immediately reported to public on social media. The Polish society has shown that it disapproves privileges of some over others.

Meanwhile, social distancing has affected public freedoms and family lives. Due to the restrictions, numerous parades, protests, and festivities had to be cancelled. In some instances, the limitation on number of participants was imposed. It led to the emergence of various social problems. Whether we consider a protest organized to fight for civic freedoms and their protection or a wedding - a significant numbers of social bodies is impacted. Some people are inevitably discriminated since their rights are not observed, or they are excluded from the possibility of participating to social, political or family event given social distancing legal restrictions. Life in the time of Covid pandemic becomes legalized anew and politicized in a new way. People who follow the rules, obey new laws and regulations, open some flexibility for future limitations of civic freedoms, authoritarianism and even dictatorship. People who disobey, in turn, put at risk the health and lives of others and could become so-called 'murderers' of others on the one hand, or guardians of democratic rules on the other hand. There are no black and white solutions, everything is relegated to the

\footnotetext{
${ }^{4}$ https://isap.sejm.gov.pl/isap.nsf/download.xsp/WDU20200000697/O/D20200697.pdf Accessed 4 June 2020.
} 
sidelines of various shades of greyish-decisions, leading to greyish consequences, the shade of which is hard to predict in the long run.

While social distancing is a war on the virus, social distancing is like a war on public space. Social distancing is a war on public culture, or the culture associated with public spaces such as in stores, restaurants, bars, public transportation, and schools. Even in the smaller scales of public life, namely through parties or large gatherings in which not all folks know each other, space is restricted. As practices associated with cultural spaces, holidays and the cancellation of holiday activities and celebrations due to Covid is the redefinition of public culture. In lieu of the unknown encounters between people who do not know each other, bubbles or pods are promoted as safe spaces for. Similarly, the home or the household, as often the source of the bubble or the pod, promoted familial relationships while discouraging the unknown public encounter. Cars even become a mobile extension of the bubble insofar as drive thru cultural operations, such as restaurants or shopping, cater to drivers who remain inside their vehicles.

\section{Positionalities of Bodies: Elbows Only, X Marks the Spot, and Sit Here Not There}

Because the purpose of physical distancing is the intentional separation of bodies and the abbreviated possible realm of bodily emissions, traditional ways of greeting one another in public are also curtailed. Hands are no longer clasped in welcoming handshakes. Arms are no longer outstretched for hugs of social embrace. Cheeks are no longer offered as expressive displays of physical warmth. Instead, elbows are offered instead as a way to express the sentiment of touch between contacts while maintaining the distance between mouths and hands. Mouths and hands are considered to be sites of possible infection and disease spread whether through touch or through breath. Through the touching of elbows, or the absence of physical touch upon greeting one another, the culture of interpersonal relationships shifts. As social distancing guidelines affect the interpersonal space that serves as the site of personal communication, the quality of interpersonal space also shifts. The body transforms from a human source of comfort and familiarity to a suspected carrier of disease.

Social distancing guidelines also transform the ways bodies position themselves in public space. In lines, or queues, the spacing between bodies becomes a vital source of regulation in the age of Covid. Distancing of six feet between bodies is called for in public venues wherever bodies might wait in line. In mapping techniques that evoke the management of forests or urban planning [25], social distancing guidelines mark an $\mathrm{X}$ on the pavement to denote exactly where the body should stand. Such projects of mapping involve cadastral logic that, as James C. Scott notes, is "a pattern of relations between local knowledge and practices on one hand and state administrative routines on the other" [25, p. 24].

In similar ways to the image below, the six-foot demarcation separates bodies of strangers, as the sample image shows the correct place to stand in terms of the rectangular marking of the spot (Fig. 2). 


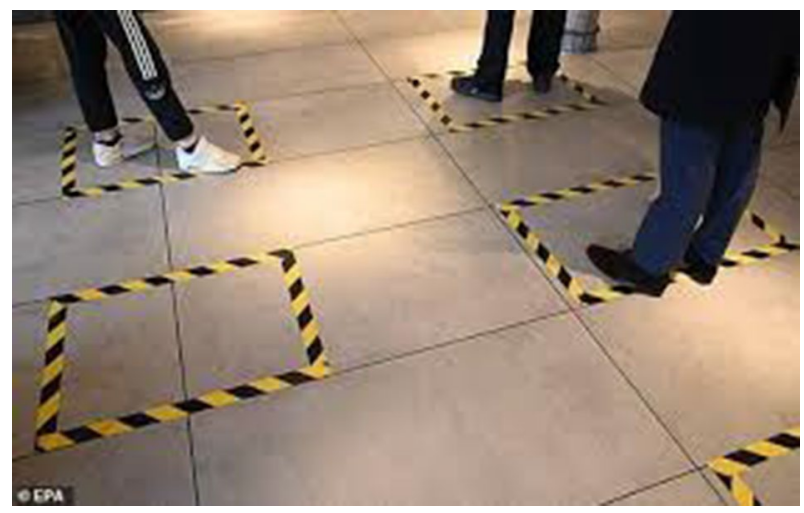

Fig. 2 Socially distanced floor markings. https://www.indiamart.com/proddetail/floor-marking-tape-forsocial-distance-22281525333.html Accessed 10 Sept 2021

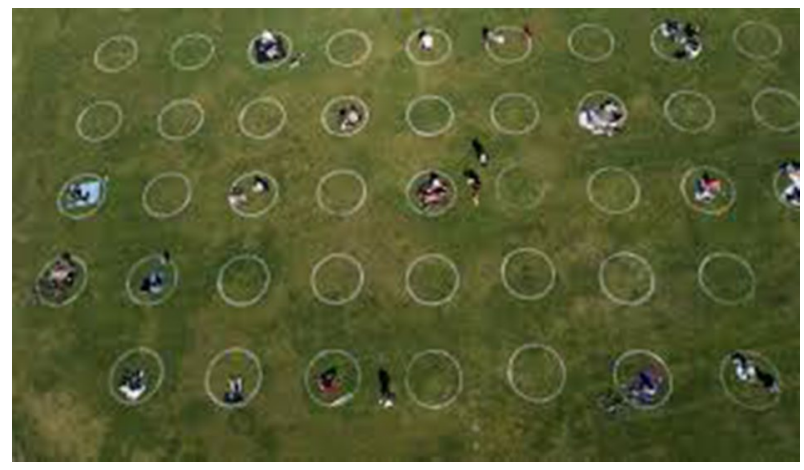

Fig. 3 Social distancing circles painted on a park lawn in San Francisco. https://www.mercurynews.com/ 2020/05/22/photos-aerial-views-of-social-distancing-circles-painted-on-dolores-park-lawn-in-san-franc isco/ Accessed 6 June 2020

Even in the spacing of socially distanced circles in outdoor parks or the statesponsored positioning of homeless bodies within rectangles drawn on the pavement, as recently transpired in San Francisco, social distancing of six feet is the new dimensionality of bodies in public space. David Delaney describes the spatial imaginary that links normativity to design insofar as the nomospheric technique of seeing the world is found in the revision of space. Delaney notes that "as nomoscapes and settings are revised-reiterative reinforcement is a form of revision-social fields of power are reconfigured" [5, p. 194]. Through the circles and rectangles of the next two images of a socially distanced public, public space is individualized through designated occupancy. Air itself, free from the possible contamination of infected droplets becomes a public resource that exists within the boundaries of the circles and the rectangles. Safe air within the boundary or at the site of the $\mathrm{X}$ in a socially distanced environment is a common-pool resource (CPR). Elinor Ostrom describes the CPR and the organization of collective action in terms of boundary creation, 


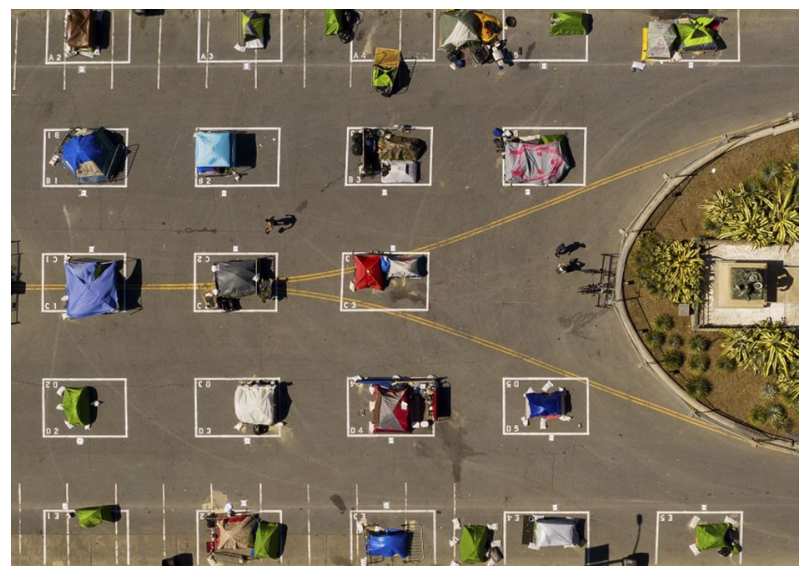

Fig. 4 Social distancing rules for homeless encampments in San Francisco. https://www.latimes.com/ world-nation/story/2020-05-22/san-francisco-sanctions-once-shunned-homeless-encampments Accessed 9 July 2020

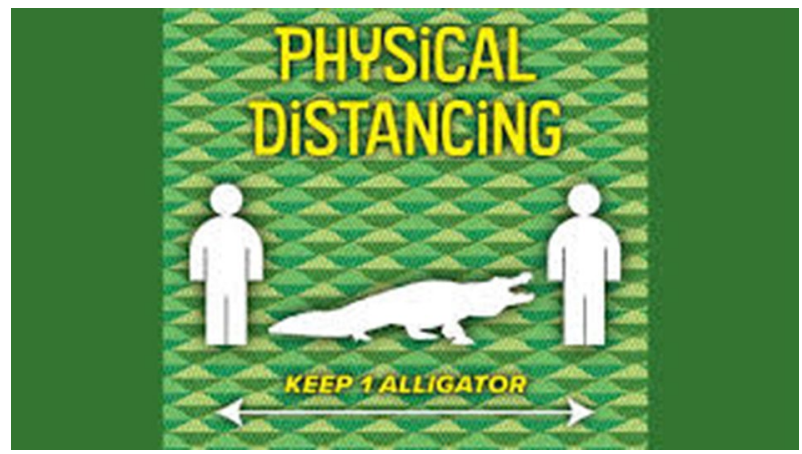

Fig. 5 Social distancing rules illustrated with an image of an alligator. https:/www.clickorlando.com/ news/local/2020/04/05/this-is-the-most-florida-way-to-remember-the-cdcs-guidelines-on-coronavirussocial-distancing/ Accessed 9 July 2020

in ways applicable to the six feet distancing parameters for the prevention of viral spread preventing the spread of Covid-19 (Figs. 3 and 4):

So long as the boundaries of the resource and/or the specification of individuals who can use the resource remain uncertain, no one knows what is being managed or for whom. Without defining the boundaries of the CPR and closing it to 'outsiders', local appropriators face the risk that any benefits they produce by their efforts will be reaped by others who have not contributed to those efforts [20, p. 91].

However, because spatial understandings reflect cultural norms, formal directions calling for six feet as the basis for social distancing are expressed in culturally 


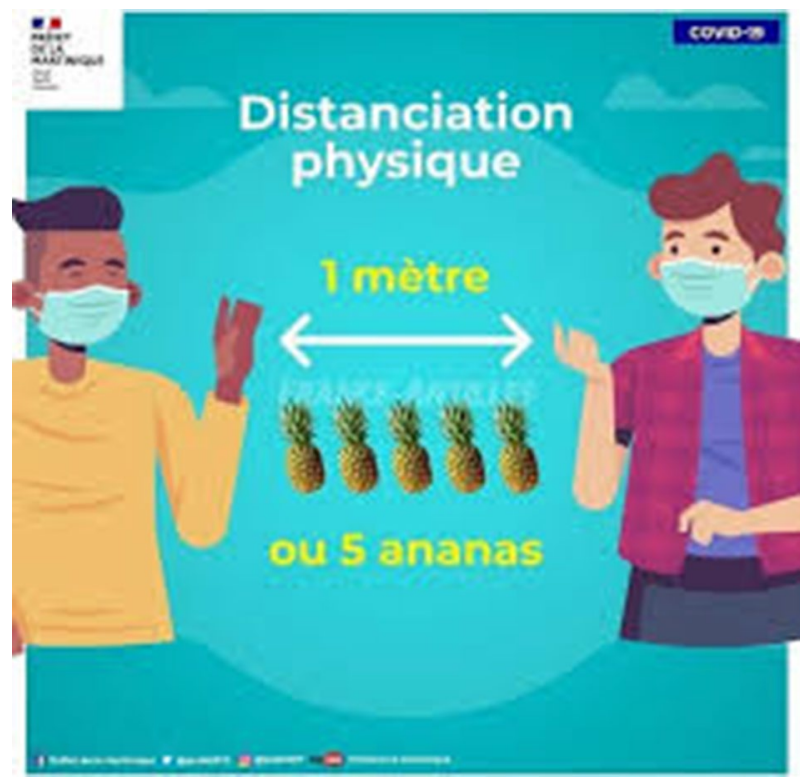

Fig. 6 Social distancing rules illustrated with 5 pineapples. https://twitter.com/JLMelenchon/status/ 1264141910085681153 ?ref_src=twsrc\%5Etfw\%7Ctwcamp\%5Etweetembed\%7Ctwterm\%5E12641419 10085681153\%7Ctwgr\%5E\%7Ctwcon\%5Es1_\&ref_url=https\%3A\%2F\%2Fwww.leparisien.fr\%2Fsoc iete $\% 2$ Fdistanciation-sociale-1-m-ou-5-ananas-1-affiche-qui-fache-23-05-2020-8322183.php Accessed 6 August 2020

relevant ways. The factors of time, space, context and communication have to be combined altogether. For instance, in Florida, the image of an alligator is used to convey the approximation of six feet in distance (Fig. 5).

In Martinique, social distancing was visually expressed with pineapples, being the third culture of Martinique cultivated in large-scale plantations, where slaves formerly served as laborers for free and in degrading conditions. As expressed by Hall [12 p.59], "culture hides much more than it reveals". So, this campaign to inform French citizens about social distance in times of Covid-19 showed inappropriate cultural codes, leading to displeasure, discontent, and public outcry on social media. Accordingly, the Prefect of Martinique withdrew it from the official website and apologized (Fig. 6).

As we move through space, another French province (Haute Savoie) use similar communication strategies to promote "physical distance" using cultural codes of high pastures with mountain ibex, cheese, mascot and pairs of skis. The perception of the visual world offered from this campaign is straightforward, less complex and certainly more positive for tourists and citizens living in this tense situation under Covid-19. Somehow, the idea is to make people more relax and more open to other types of taste (the fondue and raclette) and new sport sensations in a snowy atmosphere. So, ski resorts have to adapt to the circumstances by offering sledging, snowshoeing, cross-country or cross-country skiing, dog sledding, ice skating, but also horse sledding, paragliding, potholing, helicopter rides... (Fig. 7). 


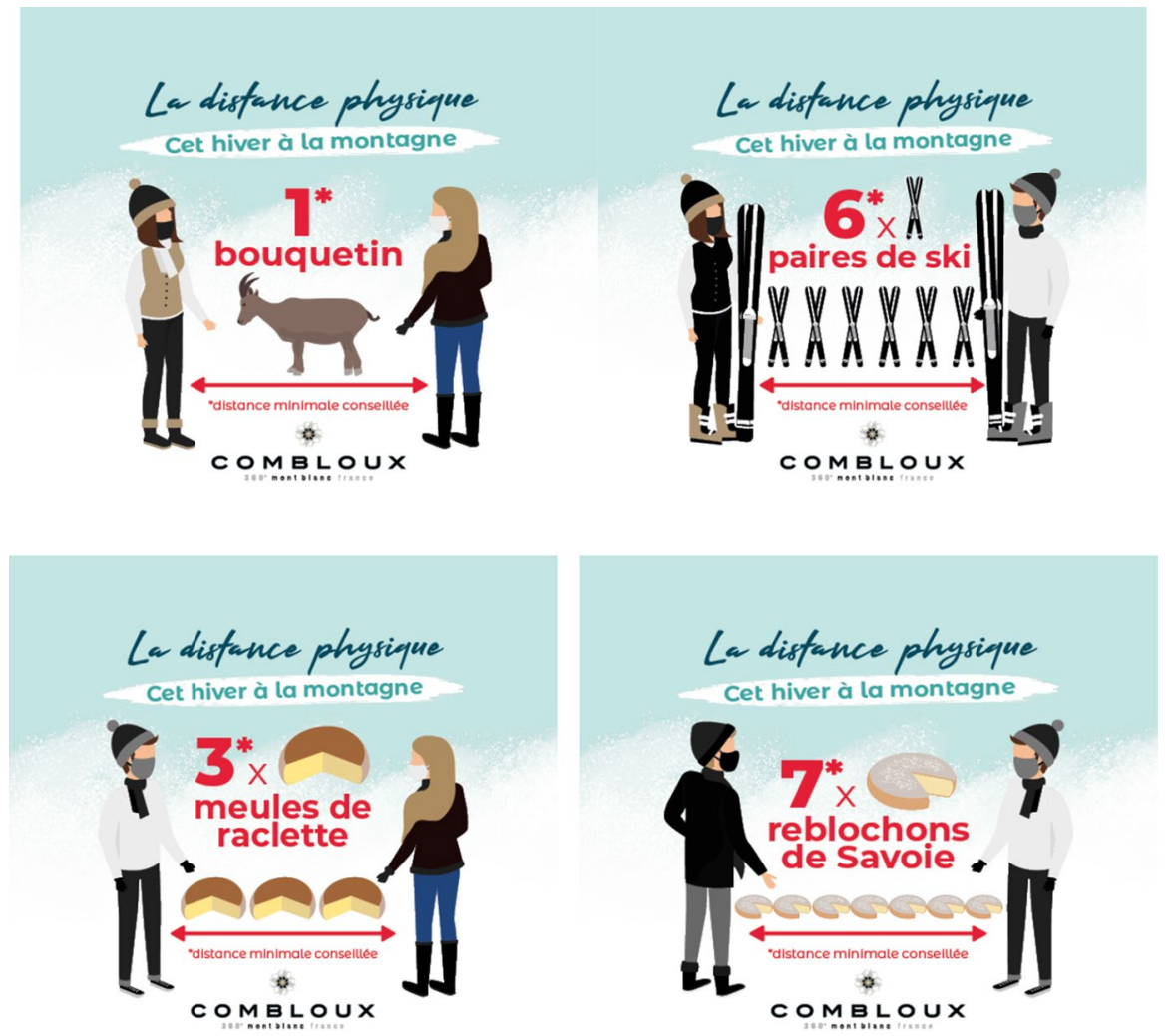

Fig. 7 Social distancing rules illustrated in various ways. https://hiver.combloux.com/infos-pratiques/ informations-covid-19.html Accessed 6 August 2020

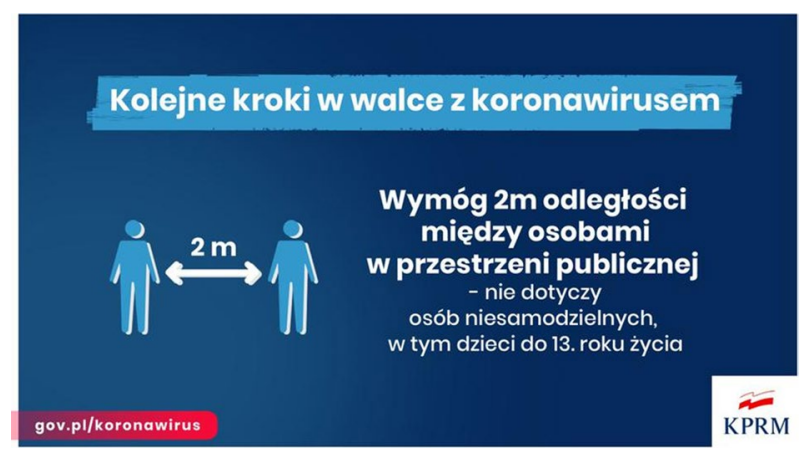

Fig. 8 Polish government social distancing graphics. https://tvn24.pl/polska/koronawirus-w-polsce-premi er-mateusz-morawiecki-oglosil-nowe-ograniczenia-lista-4520595 Accessed 6 August 2020 


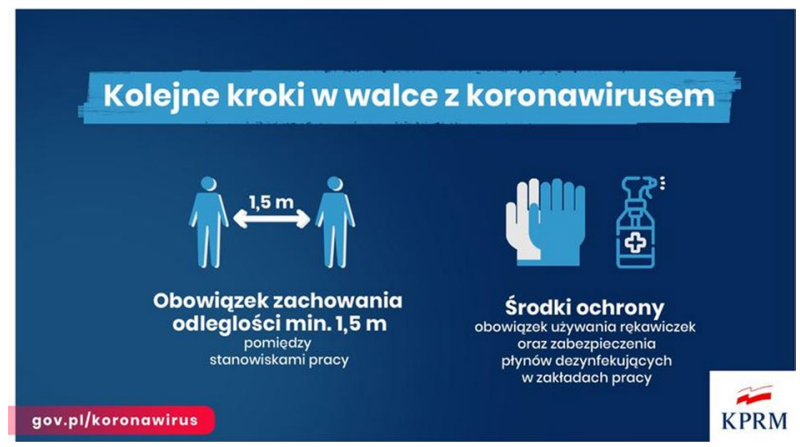

Fig. 9 Polish government social distancing graphics referring to workplaces. https://tvn24.pl/polska/ koronawirus-w-polsce-premier-mateusz-morawiecki-oglosil-nowe-ograniczenia-lista-4520595 Accessed 6 August 2020

Fig. 10 A Polish warning label. https://gft-sklep.pl/naklejkazachowaj-odstep-2-m Accessed 6 August 2020

Fig. 11 The poster placed in one of the District Electoral Commissions in Poznań (Figure taken by Aleksandra Matulewska)
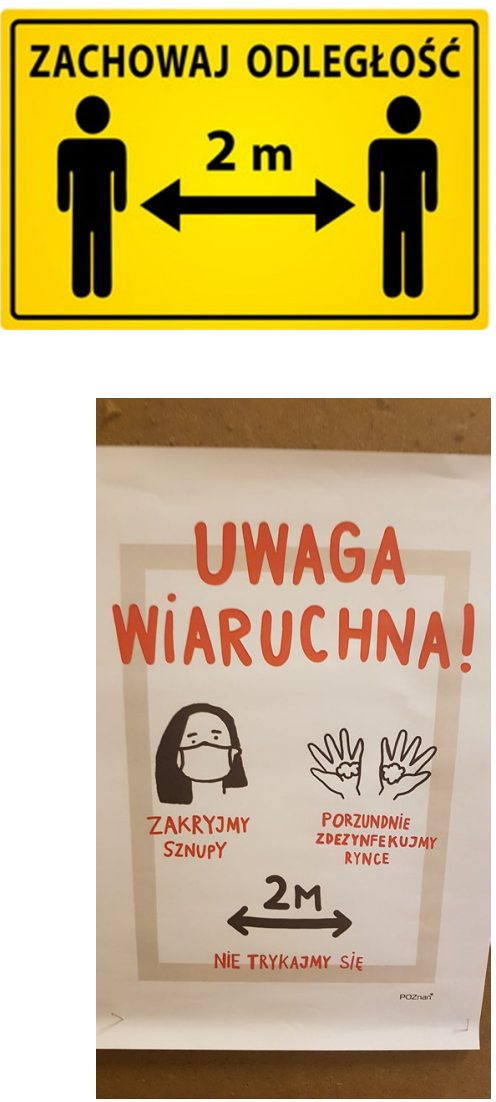


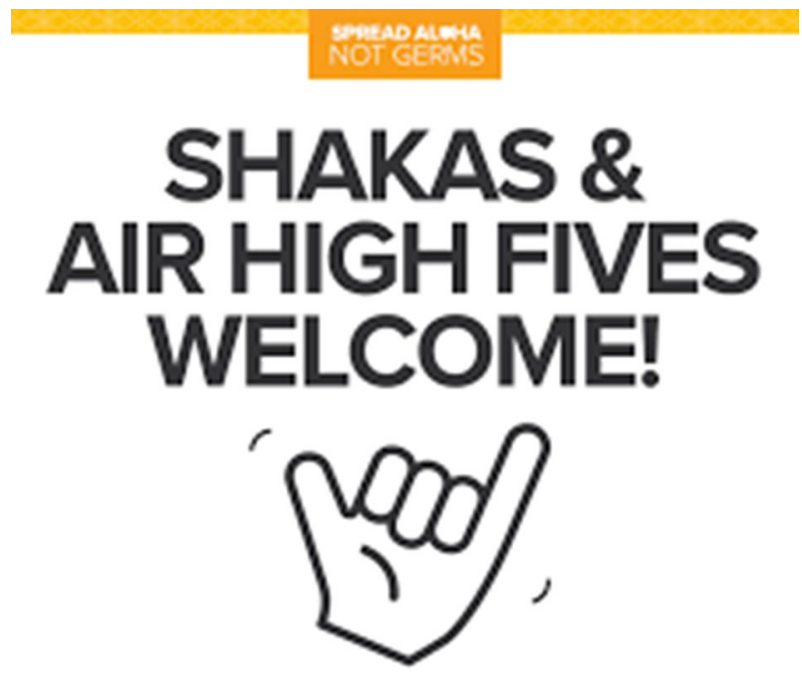

ALOHA FROM 6 FEET AWAY

Fig. 12 Greeting modes. https://www.facebook.com/KrocCenterHawaii/photos/safety-reminder-spreadaloha-from-6-feet-away-kroccenterhi-safetyfirst-spreadalo/3546868158670248/ Accessed 6 September 2020

The Polish government develops signs reminding of social distancing too. They appear in public spaces, whether displayed in physical spaces or posted online (Fig. 8).

The sign informing about the obligation to keep 2-m distance in public space does not apply to dependent persons and kids up to 13 years old (Fig. 9).

This sign informs citizens about the obligation (1) to keep $1 \mathrm{~m}$ and a half distance between work stances, (2) to wear protective gloves and disinfectants at work places. Furthermore, signs are also inspired by road signs to respect the social distance of $2 \mathrm{~m}$ (Figs. 10 and 11).

During Presidential elections, which took place in Poland on 28 June 2020 (first round) and on 12 July 2020 (second round), social distancing was enforced in various ways. Huge queues never seen before electoral commissions formed. In the premises of the District Electoral Commissions in Poznań, the posters were formulated in local dialect. The aim of the dialect usage was not to communicate more efficiently since the dialect is actually disappearing and the official Polish prevails in public and private spaces, but to cheer voters up.

In Hawai'i, the greeting of aloha is typically shared through a hug or extensive handshake. However, in times of Covid, the physicality of aloha is replaced with the gentle twisting of a fist in the air with thumb and pinky finger extended. Known locally as the 'shaka', spreading aloha without physical touch becomes the optimal way to spread aloha (hello), as shown in one example below (Fig. 12). 


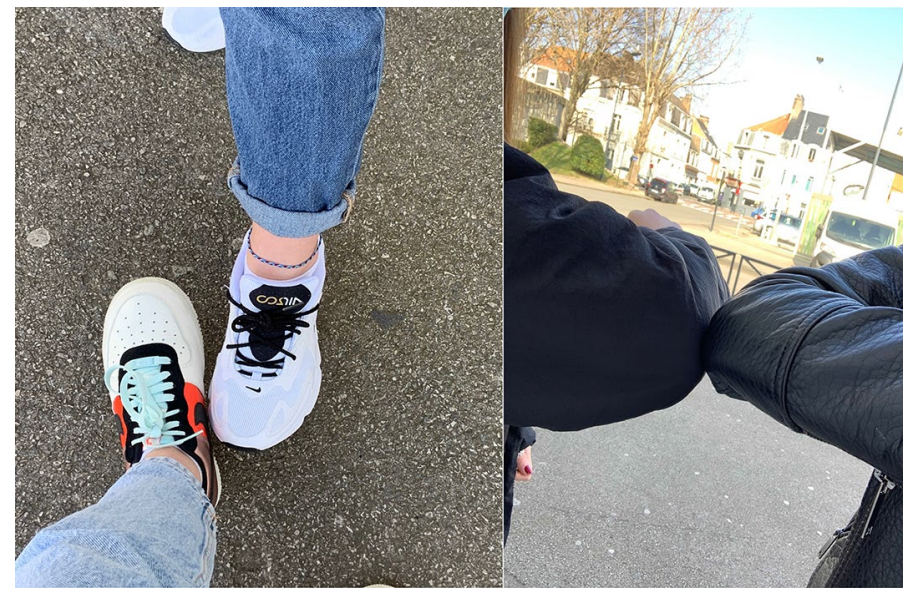

Figs. 13 New methods of greetings in photos. Wagner's figure: The foot shake, the elbow bump

To decrease the potential virus spread, new types of techniques have been promoted worldwide, not only in France to greet others. France has a reputation for its cheek kisses, one in Brittany, two in northern France, sometimes three or even four depending on the French regions. France is also known for its handshakes. But with Covid-19, kissing each other or hand-shaking is no longer possible. Citizens in France but also worldwide had to invent a new cultural code that they copied from other countries worldwide. The foot shake was originally coming from Wuhan, known as the "Wuhan shake" and now culturally transplanted in other regions of the world as the "foot shake", whereas others prefer the "elbow bump", originally from the Ebola epidemic. Cultural codes were easily transferable from one country to another via different videos posted on YouTube [7] to promote this new welcoming style (Figs. 13 and 14).

Other styles are much more culturally oriented towards South-East Asia (Natmaste or Wai), or African countries, and so less easily applicable to European countries. The WHO has promoted a leaflet to explain how best greet others for Africa (Fig. 15).

In the Republic of Poland, the typical three kisses in the cheeks or handshakes have been replaced which shaking elbows or touching with clenched fists. The kids at school have been discouraged to participate in normal social interactions. They are no longer encouraged to be friendly and supportive in a traditional sense. They are not allowed to exhibit friendly attitudes, such as food sharing or lending a pencil or a crayon to a schoolmate. The social distancing and the limitation of the virus spreading is going to deepen anti-social attitudes that schools have been trying to combat for some time. The negative unfriendly attitudes to schoolmates, including discriminatory ones have transformed from negative (egoistic and egocentric) to recommended (reasonable, healthy and safe) modes of behavior.

Making the distance relevant to what people may typically understand as they consider how to gauge six feet without actual measurement also comes in the form 


\section{COVID-19 PREVENTION}

\section{Greetings}

Limit close contact with others,

especially if they are showing flu-like symptoms.

\section{ENCOURAGE}

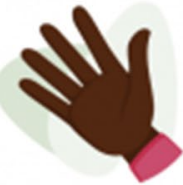

Nodding

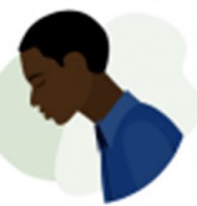

Touching elbows

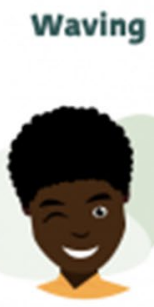

Bowing

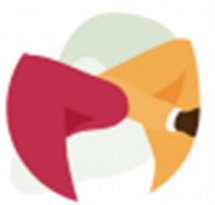

AVOID

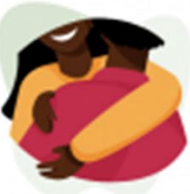

Hugging

Shaking

hands
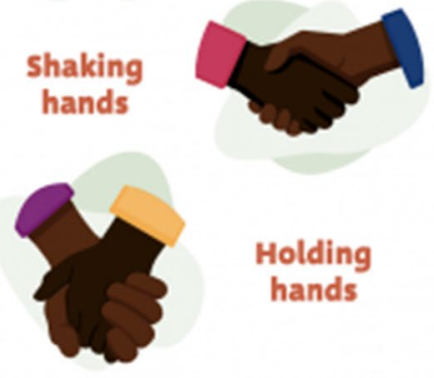

Holding

hands

Kissing

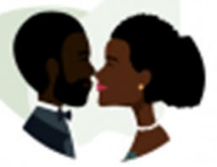

Fig. 14 Instructions on greetings [31]

of recognized shopping cultural tools: the length of the store buggy, as seen below (Fig. 16).

As in standing, seating of the public is also subject to social distancing guidelines. Again, X marks the spot in blocking off spaces that are too close to one another. In his discussion of lines, Tim Ingold speaks of a "comparative anthropology of the line" $[13$, p. 1]. The linearity of the six-foot designation of intentionally emptied space between bodies is the embodied positioning of linear space that serves as the cultural instructions for standing in such a way that actively contributes to fighting viral spread. Such standards of regulating place are effectively a form of zoning, as 


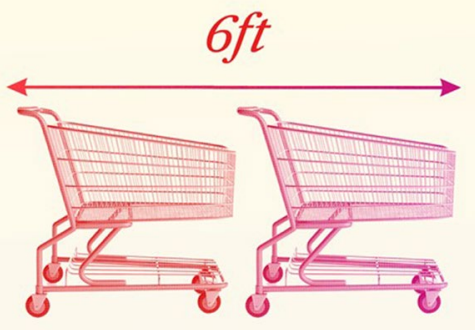

Fig. 15 Six-feet social distancing rules. https://www.today.com/health/why-six-feet-apart-social-dista ncing-guidelines-during-coronavirus-pandemic-t177136 Accessed 6 August 2020

Fig. 16 Social distancing seating arrangements. https://www. channel3000.com/marcus-theat res-introduces-social-distancingseating-arrangements/ Accessed 6 August 2020

\section{SOCIAL DISTANCING SEATING ARRANGEMENTS}

\section{SCREEN}

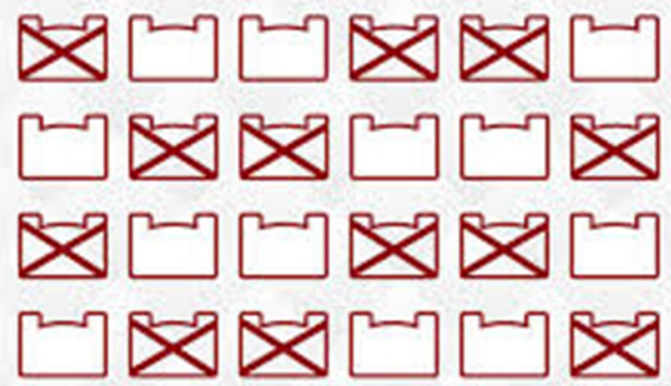

a design standard for preventing infection [3] in which areas of space are open for occupancy while others are not (Fig. 17).

In France and Poland, physical distance is achieved by leaving an empty seat between schoolkids, patients, passengers, etc. In numerous places where queues form naturally, separation lines are displayed on the floor, which visually show the allowed physical distance between people. In Poland, the zoning is marked with tapes either in (1) yellow and black, (2) red and white or (3) red (Figs. 18, 19 and 20).

The colors used are symbolic in many respects. The yellow and black signs are typical danger warning road signs in compliance with the Vienna Convention on Road Signs and Signals of 1968. Analogously, red and white are used in prohibitory or restrictive signs [32]. White and red are used to indicate the distance as well. The Convention states that "Danger warning signs shall be placed at such distance from the 


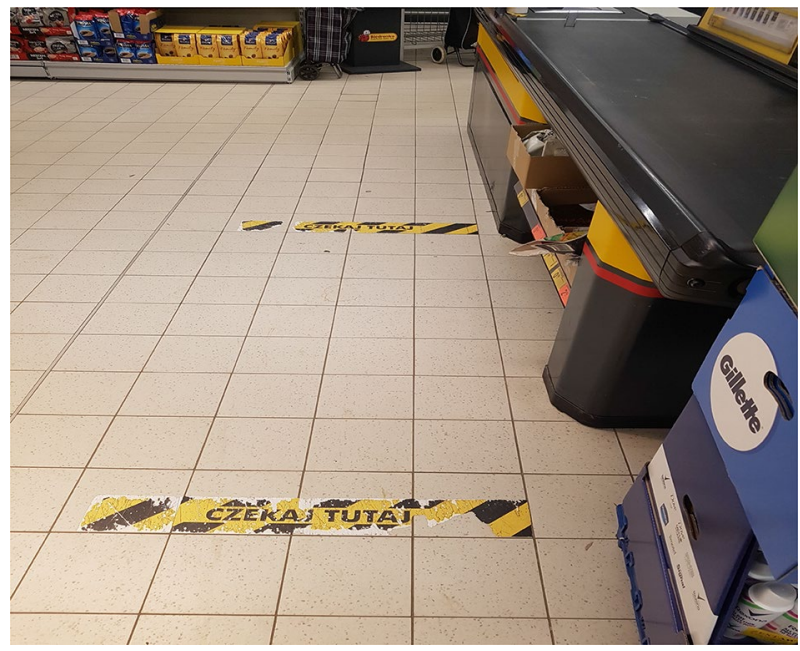

Fig. 17 Yellow and black social distancing tapes on the supermarket floor informing "Wait here" (Figure taken by Aleksandra Matulewska)

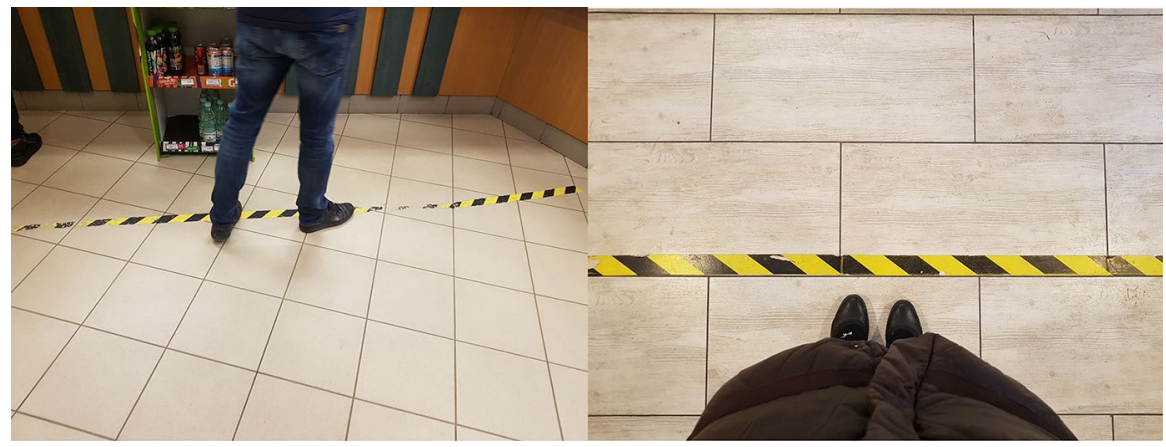

Figs. 18 Yellow and black social distancing tapes on the post office and restaurant floors respectively, indicating the recommended distance in public spaces (Figure taken by Aleksandra Matulewska)

danger point as will make them most effective both by day and by night" [27, p. 10]. Red in turn is the color traditionally associated with the devil, hell, fire, anger, outrage, danger, blood, but also love. Both red and yellow are used for instance in sports to signal a breach of rules (a yellow card is a warning) and subsequent admonitions (a red card) [17]. Therefore, the symbolism of colors is heavily exploited, in various signs, reminding about Covid-related restrictions in Poland. 


\section{Stranger Danger: Bubbles, Pods, and the Safety the Household}

In addition to social distancing guidelines, there are also guidelines for social interactions. The bubble or pod is an intentional group of people who know each other well enough to hang out with each other. The bubble or pod is expected to counter the dangers of spontaneous interaction within a restriction of interactions of those within the bubble. Ideally a closed network, some bubbles or pods are leaky with the result being a "false sense of security" [11] in terms of protection against the virus. The household often a source of the bubble, or the overlap of households that routinely see each other socially. As a place of refuge, the home is spatially prioritized during Covid as the idealized site of safety, except when infection reaches a multigenerational household, for example. Yet, the critique of the bubble or the pod as premised upon the household is one in which Margaret Kohn [14] critiques the lack of encounter in meeting new people, or strangers, in maintaining the social health of public spaces that is vitally for democracy. During Covid, the fear of stranger danger is intensified and justified through the prevention of viral spread. However, assumptions are rampant, or as Rachel Gutman [11] states, "Sorry to burst your quarantine bubble". The homeless or houseless are further marginalized as physically lacking a central location of safety for the bubble to transpire.

\section{Spatialized Transformation of Cultural Activities and Everyday Capitalist Banalities}

In this war on space, bodies are positioned according to social distancing guidelines, local cultural knowledge is harnessed, and relationships are narrowed and minimized through covid bubbles. Whether in public spaces or the household, restrictions on spatial gathering and cultural customs of greeting are redefined for purposes of preventing viral spread. Even in public spaces, custom and behaviors are spatialized according to size and population sparsity. Parties and gatherings are limited in size and scope, shopping centers become empty as occupancy figures are limited in scope, and restaurants and bars have shrunk in size as well as sheer existence. Interestingly, the car has become an extension of the covid bubble. Through its mobility and individualized spatialization, the vehicle can drive to pick up food, to pick up shopping orders, even for Covid testing performed through the window of either the driver and/or passenger doors. Cars with passengers inside waving have become the new norm for high school and college graduations. Even the New Hampshire State Legislature has taken to using the car as a privatized bubble through which to hold official session in an open-air parking lot [2] 


\section{Conclusion}

In order to slow and hopefully stop the spread of the Covid-19 virus, a war on space is taking place. Public space is no longer free to inhabit. Cultural space is no longer open for public exchange. Social space has been politicized through official mandates that either supported or refused to acknowledge the dropletbased spread of this coronavirus. Stranger danger has justified covid bubbles, even leaky ones, that create pods of people who select their own interaction. The car has replaced physical embodiment in representing a new mobile type of bubble that can do many of the same things the person used to be required to do (go to the store, attend graduation ceremonies, even attend legislative session). The war on space that hopefully will be won with the help of global vaccinations will hopefully not completely decimate human interaction that spontaneously inhabits spaces and places in ways that reject regulation and conformity.

The new space bubbles also replace traditional human interactions considerably changing life of various social strata. It is no longer acceptable to be friendly, cordial and empathic in a traditional sense. Friendliness, which so far has been considered to be warmth and kindness to others, becomes reformulated and remodeled. It acquires a new semantic meaning. Warmth is replaced with secure physical distance. Kindness has been understood as caring for the well-being of another person, but right now it encompasses refraining from helping others since it is a risk of virus spreading. Laws impose new understanding of civic duties and pleasantries. Time will show whether the new behavior imposed by the legal environment to combat Covid-19 pandemic, especially for younger generations, will turn out to be short or long-lasting. Should new modes of social behavior being solidified, health issues on depression, social ostracism, and other social disorders may increase given the loss of a sense of belonging and of reliance on others.

Within modern societies, people are taught to distance themselves from others and to limit their human interactions, especially direct and fact-to-face ones. Human interactions become digitalized, friendships are no longer associated with hugs, kisses and physical support. They focus on chats and virtual communication. Even people who live under the same roof send each other birthday wishes and greeting cards via social media. At this stage, the future of social post-Covid interaction is hard to predict. The time will show whether people tormented by hunger of social interactions will come back to traditional socializing modes, or entertaining themselves with social-distancing will become their second nature. The 'new normal' of social/physical distancing may become our second skin. The positionalities of bodies that contribute to the transformation of cultural spaces and social interactions against the legalized backdrop of combatting viral spread of Covid-19 may have much longer impact on societies than ever expected. Besides, the change may be faster and more permanent than predicted. Accordingly, two possible scenarios can be predicted. Firstly, the legal restrictions, designed as a temporary necessity for the pandemic period, may be obeyed well after they are lifted. Secondly, societies, tired of restrictions, may crave the old normality so much, that they may overindulge in traditional ways of living and interacting. 


\section{References}

1. Associated Press. 2020. Trump Says Federal Social Distancing Guidelines Will Not Be Extended at the End of the Month. Available at https://www.marketwatch.com/story/trump-says-federal-socialdistancing-guidelines-will-not-be-extended-at-the-end-of-the-month-2020-04-29. Accessed 24 Feb 2021.

2. Barry, Ellen. 2021. As State Legislatures Aim to Convene Amid Covid, One Tries a Drive-In. New York Times, January 7, 2021. Available at: https://www.nytimes.com/2021/01/07/us/new-hampshiredrive-in-legislature.html. Accessed 25 Feb 2021.

3. Ben-Joseph, Eran. 2005. On Standards. In Regulating Place: Standards and the Shaping of Urban America, ed. Eran Ben-Joseph and Terry S. Szold, 1-14. New York: Routledge.

4. Bennett, M.J. 1998. Intercultural Communication: A Current Perspective. In Basic Concepts of Communication. Selected Readings, ed. M.J. Bennett, 134. Yarmouth, Maine: Press Inc.

5. Delaney, David. 2010. Nomospheric Investigations: The Spatial, the Legal and the Pragmatics of World-Making. New York: Routledge.

6. Facebook post of Kancelaria Premiera. 202, March 31. https://www.facebook.com/kancelaria.premi era/posts/10158512142494653/. Accessed 2 Mar 2021.

7. Footshakes and Elbow Bumps: New Coronavirus Greetings. https://www.youtube.com/watch?v=12Yui6PdWI. Accessed 2 Mar 2021.

8. French Decree no 2021-76, 27 janvier 2021 modifiant les décrets no 2020-1262 du 16 octobre 2020 et no 2020-1310 du 29 octobre 2020 prescrivant les mesures générales nécessaires pour faire face à l'épidémie de covid-19 dans le cadre de l'état d'urgence sanitaire. https://www.legifrance.gouv.fr/ jorf/id/JORFTEXT000043070201?r=b3tphenSAH. Accessed 2 Mar 2021.

9. French Decree no 2020-1262. 16 Octobre 2020 prescrivant les mesures générales nécessaires pour faire face à l'épidémie de Covid-19 dans le cadre de l'état d'urgence sanitaire. https://www.legif rance.gouv.fr/jorf/id/JORFTEXT000042430554?r=JPSYOue1ju. Accessed 2 Mar 2021.

10. Gov.pl. 2020. Kolejne kroki w walce $\mathrm{z}$ koronawirusem-w sklepie mniej osób, ograniczenia w poruszaniu nieletnich, a parki, plaże i bulwary zamknięte https://www.gov.pl/web/koronawirus/kolej ne-kroki. Accessed 2 Mar 2021.

11. Gutman, Rachel. 2020. Sorry to Burst Your Quarantine Bubble. The Atlantic, November 30, 2020. Available at: https://www.theatlantic.com/health/archive/2020/11/pandemic-pod-bubble-conceptcreep/617207/. Accessed 25 Feb 2021.

12. Hall, Edward T. 1998. The Power of Hidden Differences. In Basic Concepts of Communication. Selected Readings, ed. M.J. Bennett, 5368. Yarmouth, Maine: Press Inc.

13. Ingold, Tim. 2016. Lines: A Brief History. New York: Routledge.

14. Kohn, Margaret. 2004. Brave New Neighborhoods: The Privatization of Public Space. New York: Routledge.

15. Koronawirus. RPO: zakazy wchodzenia do lasu-bez podstawy prawnej. https://www.rpo.gov.pl/ $\mathrm{pl} /$ content/koronawirus-rpo-brak-podstawy-prawnej-zakazu-wchodzenia-do-lasu. Accessed 2 Mar 2021.

16. Landot \& Associés Avocats à la Cour. website: https://blog.landot-avocats.net/2021/02/02/selonletat-la-nouvelle-distance-sociale-de-2m-ne-sappliquerait-pas-en-restauration-scolaire-mais-gardo ns-nos-distances-face-a-cette-interpretation/. Accessed 2 Mar 2021.

17. Macron Président de la République Française. 2020. Adresse aux Français. https://www.elysee.fr/ emmanuel-macron/2020/11/24/adresse-aux-francais-24-novembre. Accessed 12 Mar 2021.

18. Matulewska, Aleksandra, and Dariusz J. Gwiazdowicz. 2020. Cyberbullying in Poland: A Case Study of Aggressive Messages with Emojis Targeted at the Community of Hunters in Urbanized Society. Social Semiotics 30 (3): 379-395. https://doi.org/10.1080/10350330.2020.1731194.

19. Open Letter to the Minister of Environment on the ban of National Forests from the Polish Commissioner for Human Rights https://www.rpo.gov.pl/sites/default/files/RPO\%20do\%20Ministra\% 20\%C5\%9Arodowiska\%20ws\%20wst\%C4\%99pu\%20do\%201as\%C3\%B3w\%2C\%207.04.2020.pdf. Accessed 2 Mar 2021.

20. Ostrom, Elinor. 1990. Governing the Commons: The Evolution of Institutions for Collective Action. New York: Cambridge University Press.

21. Philippe, Edouard. 2020. Gouvernement.fr Website. Déclaration de M. Édouard PHILIPPE, Premier ministre, sur le Covid-19. https://www.gouvernement.fr/partage/11444-declaration-de-m-edouardphilippe-premier-ministre-sur-le-covid-19. Accessed 2 Mar 2021. 
22. Regulation of the Council of Ministers of April 19, 2020 on the establishment of certain restrictions, orders and bans in connection with the epidemic [Rozporządzeniem Rady Ministrów z dnia 19 kwietnia 2020 r. w sprawie ustanowienia określonych ograniczeń, nakazów i zakazów w związku z wystąpieniem stanu epidemii]. https://isap.sejm.gov.pl/isap.nsf/download.xsp/WDU2020000 0697/O/D20200697.pdf. Accessed 2 Mar 2021.

23. Regulation of the Council of Ministers of March 31, 2020 on the establishment of certain restrictions, orders and bans in connection with the epidemic [Rozporządzeniem Rady Ministrów z dnia 31 marca 2020 r. w sprawie ustanowienia określonych ograniczeń, nakazów i zakazów w związku z wystąpieniem stanu epidemii]. https://isap.sejm.gov.pl/isap.nsf/download.xsp/WDU2020000 0566/O/D20200566.pdf. Accessed 2 Mar 2021.

24. Rémi Salomon. 2020. Vidéo-Confinement à Noël. https://www.francetvinfo.fr/sante/maladie/coron avirus/confinement/video-confinement-a-noel-on-coupe-la-buche-en-deux-et-papy-et-mamie-mange nt-dans-la-cuisine-preconise-le-professeur-salomon_4193521.html. Accessed on 12 Mar 2020.

25. Scott, James C. 1998. Seeing Like a State: How Certain Schemes to Improve the Human Condition Have Failed. New Haven: Yale University Press.

26. Simulation de la Propagation des Gouttelettes. https://www.youtube.com/watch?v=Sw2oaU85JKg. Accessed 2 Mar 2021.

27. Vienna Convention on Road Signs and Signals concluded in Vienna on 8 November 1968. https:// unece.org/DAM/trans/conventn/Conv_road_signs_2006v_EN.pdf. Accessed 2 Mar 2021.

28. Ważna, Magdalena. 2020. Pacjent "zero" z koronawirusem w Polsce stał się sławny. Co z ochroną danych osobowych? https://www.medonet.pl/koronawirus/koronawirus-w-polsce,pacjent-zero-zkoronawirusem-w-polsce-stal-sie-slawny--co-Z-ochrona-danych-osobowych-, artykul,38474051. html. Accessed 2 Mar 2021.

29. White House Official Webpage. Priorities: Covid-19: The Biden-Harris Plan to Beat Covid-19. https://www.whitehouse.gov/priorities/covid-19/. Accessed 24 Feb 2021.

30. World Health Organization Webpage. Coronavirus Disease (COVID-19) Advice for the Public. https://www.who.int/emergencies/diseases/novel-coronavirus-2019/advice-for-public. Accessed 2 Mar 2021

31. World Health Organization Webpage. Coronavirus (Covid-19) Prevention-Greetings. https://www. afro.who.int/publications/coronavirus-covid-19-prevention-greetings. Accessed 2 Mar 2021.

32. Wagner, Anne. 2006. The Rules of the Road, A Universal Visual Semiotics. International Journal for the Semiotics of Law 19 (3): 311-324. https://doi.org/10.1007/s11196-006-9025-x.

Publisher's Note Springer Nature remains neutral with regard to jurisdictional claims in published maps and institutional affiliations. 